\title{
Mitigation of Hydrodynamic Resistance
}

Methods to Reduce Hydrodynamic Drag 
This page intentionally left blank 


\section{Mitigation of Hydrodynamic Resistance Methods to Reduce Hydrodynamic Drag}

\section{Marc Perlin • Steven Ceccio}

University of Michigan, USA 


\section{Published by}

World Scientific Publishing Co. Pte. Ltd.

5 Toh Tuck Link, Singapore 596224

USA office: 27 Warren Street, Suite 401-402, Hackensack, NJ 07601

UK office: 57 Shelton Street, Covent Garden, London WC2H 9HE

\section{Library of Congress Cataloging-in-Publication Data \\ Perlin, Marc.}

Mitigation of hydrodynamic resistance : methods to reduce hydrodynamic drag / by Marc Perlin (University of Michigan, USA), Steven Ceccio (University of Michigan, USA). pages $\mathrm{cm}$

Includes bibliographical references and index.

ISBN 978-9814612258 (alk. paper)

1. Ships--Hydrodynamics. 2. Ship resistance. 3. Hulls (Naval architecture) I. Ceccio, S. L. (Steven L.) II. Title.

VM751.P44 2015

623.8'1015325--dc23

2014031056

\section{British Library Cataloguing-in-Publication Data}

A catalogue record for this book is available from the British Library.

Copyright $(C) 2015$ by World Scientific Publishing Co. Pte. Ltd.

All rights reserved. This book, or parts thereof, may not be reproduced in any form or by any means, electronic or mechanical, including photocopying, recording or any information storage and retrieval system now known or to be invented, without written permission from the publisher.

For photocopying of material in this volume, please pay a copying fee through the Copyright Clearance Center, Inc., 222 Rosewood Drive, Danvers, MA 01923, USA. In this case permission to photocopy is not required from the publisher.

In-house Editors: Sutha Surenddar/Steven Patt

Typeset by Stallion Press

Email: enquiries@stallionpress.com 
To Terry and Martha 
This page intentionally left blank 


\section{Preface}

This text is written for scientists and engineers who are interested in various aspects of, and techniques to reduce the drag forces on objects moving at or below a liquid surface. Although there is a combination of experimental, numerical, and analytical material presented, the dominant focus is experimental in nature. Numerical investigations have aided understanding of the underlying physical mechanisms associated with flow induced skin friction and its reduction; however, numerical efforts are often limited by the computational resources needed to simulate large Reynolds number flows at large scales. That is, a typical surface ship in the ocean environment operates at Reynolds numbers of about $10^{9}$ with lengths of $100 \mathrm{~m}$ or more, hence the focus on experiments. As always, the best approach is a thoughtful combination of experiment, computation, and analysis.

Senior undergraduate students who have successfully completed a course or more in fluid mechanics and graduate students, who have done likewise, can master the material in this book. Practicing engineers who desire knowledge in this area will also find the material acceptable and useful as well as easily grasped and mastered. 
This page intentionally left blank 


\section{Acknowledgments}

To all of the Graduate students who have facilitated this research, we acknowledge your dedication and extremely difficult efforts at the US Navy's Large Cavitation Channel and at the University of Michigan. Experimental research is very difficult to conduct, especially at these large scales and expensive facilities. These students include Dr. Wendy Sanders, Dr. Eric Winkel, Dr. Brian Elbing, Dr. Ghanem Oweis, Dr. Simo Makiharju, Dr. Keary Lay, Dr. Andrew Wiggins, Dr. Xiaoshun Shen, Dr. Jinhyun Cho and Dr. Ryo Yakushiji, and Mr. James Gose and Ms. Sarah Schinasi.

To our colleagues, Professors David R. Dowling and Michael J. Solomon, we thank you for your collaboration, effort, and technical insights.

Thanks to our colleagues at the Naval Surface Warfare Center, Carderock Detachment, especially Mr. Robert Etter, and the staff at the Memphis Detachment, especially Dr. Michael Cutbirth, H. Paul Julian, and all the many technicians at the Large Cavitation Channel. As did our colleagues at UM, you made our work successful there and as much fun as it could be under the strenuous conditions and long hours.

We are indebted to the sponsors of many of these investigations, the Defense Advanced Research Project Agency, and the Office of Naval Research. We would like to thank Dr. Lisa Porter, Dr. Thomas Buetner, Dr. Pat Purtell, and Dr. Ki-Han Kim.

Lastly, we thank the University of Michigan for the opportunity to prosper and conduct our research as we choose. To date, both of us have spent our entire academic careers there, and for this we are appreciative. 
This page intentionally left blank 


\section{Contents}

Preface vii

Acknowledgments ix

Chapter 1. Introduction 1

References ............... 4

Part I. Active Techniques 5

Chapter 2. Modification of Drag by Polymer Injection 7

2.1 Background Information . . . . . . . . . 7

2.1.1 Inner variables and scaling . . . . . . 7

2.1.2 Background for PDR . . . . . . . . . 10

2.2 Internal Flows at High Re . . . . . . . . . . . . 15

2.3 External Flows and PDR . . . . . . . . . 20

2.3.1 The experiments of Winkel et al. (2009) ............ . . 21

2.3.2 $K$-factor scaling of PDR ...... 25

2.3.3 The effects of roughness on FDR in a TBL - the experiments of Elbing et al. (2011) . . . . . . . . 27

2.3.4 Another study on surface roughness effects but conducted at smaller $\operatorname{Re} \ldots \ldots . . . . . .$. 
2.4 Polymer Release with Coatings . . . . . . .

References ................ . . 45

Chapter 3. Friction Drag Reduction by Bubble/Gas Injection 49

References ............... 66

Chapter 4. Transition from BDR and Air Layer Drag Reduction 71

4.1 Transition from BDR to ALDR . . . . . . . . 71

4.2 Scaling of Air Layer Formation . . . . . . . . . . . 78

4.3 Air Layers on Ship Models . . . . . . . . . . 79

References ............... 82

Chapter 5. Friction Drag Reduction by Partial Air Cavities or PCDR 83

5.1 PCDR on the HIPLATE Model . . . . . . . . 83

5.2 Comparison of Air Flux and Pumping Energy Requirements for ALDR and PCDR . . . . . 92 References . . . . . . . . . . . . 98

\section{Part II. Passive Techniques}

Chapter 6. Drag Reduction by Super and Partial Cavities 103 References . . . . . . . . . . . 120

Chapter 7. Super-Hydrophobic Surfaces and Coatings

References ..............

Chapter 8. Passive Resistance-Mitigation by Appendages:

Bulbous Bows, Stern Flaps and Wedges, and Lifting Bodies

8.1 The Bulbous Bow . . . . . . . . . . . . 137

8.2 Stern Flaps, Wedges, and Bulbs . . . . . . 138

8.3 Lifting Bodies . . . . . . . . . . . . . 140

References . . . . . . . . . . . . . 145 